\title{
Effectiveness of Training Sessions on a Measure of Optimism and Pessimism Concepts among the Kindergarten Children in the District of Al-Shobak in Jordan
}

\author{
Reham Mohammad Al-Mohtadi ${ }^{1, *}$, Intisar Turki ALdarab'h² \& Al-Mothana Moustafa Gasaymeh ${ }^{3}$ \\ ${ }^{1}$ Curricula and Methods of Teaching Kindergarten, Department of Curriculum and Teaching, School of Education, \\ Al-Hussein Bin Talal University, P.O. Box (20), Ma'an, Jordan \\ ${ }^{2}$ Early Childhood of Education, Department of Curriculum and Teaching, School of Education, Al-Hussein Bin Talal \\ University, P.O. Box (20), Ma'an, Jordan \\ ${ }^{3}$ Instructional Technology, Department of Curriculum and Teaching, School of Education, Al-Hussein Bin Talal \\ University, P.O. Box (20), Ma'an, Jordan \\ *Correspondence: Curricula and Methods of Teaching Kindergarten, Department of Curriculum and Teaching, \\ School of Education, Al-Hussein Bin Talal University, P.O. Box (20), Ma'an, Jordan. E-mail: \\ jordanian81@hotmail.com
}

Received: May 18, 2015

Accepted: July 8, 2015 Online Published: August 10, 2015

doi:10.5430/wje.v5n4p81

URL: http://dx.doi.org/10.5430/wje.v5n4p81

\begin{abstract}
The current study aimed to examine the effects of training sessions on children's levels of optimism versus pessimism. among the kindergarten children in the district of Shobak in Jordan. The sample of the study consisted 21 children whom their ages were between 5 to 6 years old. A training program was applied. The level of optimism and pessimism among the kindergarten children were measured through the use of notes cards consisted from 12 items. The results of the study showed that there were significant differences in the level of optimism versus pessimism based among participants' before and after applying the program in favor of the post- measure.
\end{abstract}

Keywords: Optimism, Pessimism, Kindergarten Children

\section{Introduction}

Kindergarten children are is the future fathers and mothers. As educators, we should prepare the mind provide them with the appropriate behaviors and actions that lead to build their personalities from all sides that included, (motor, moral, cognitive and skill). No doubt that parents hope that their children will be without problems and they would enjoy friendly relations with the others, approaching life and having the hope in better future, having the challenge and the insistence to continue life in its blessing and malice. However, these wishes will not be achieved unless children' parents and teachers know how to deal with the children, and how to explain in front of them the life positions in an optimistic picture, and how they make them acquire the optimistic behavior, and to get them away from the pessimistic behavior.

No doubt that the pessimistic, aggressive and languish acts by our children had resulted from the ways in which we deal with them whether in the family or in the kindergarten. Today, we are living in an era that characterizes by change in every moment, these changes affect the speed of our rhythm, and on our follow-up and upbringing our children. It is insufficient to educate our children how to love and to care rather we need to contemplate, review and check out our behaviors with them (Bdair, 2011).

Vaughan (2000) viewed optimism as a tendency or inclination to look at the better side of the events and predicting the best practices, more of the attempt, avoiding shame and introversion. While pessimism was viewed as psychological state based on disper and looking at the things from the bad side, and thinking that everything is going wrong. Enhancing the optimistic point of view makes the children more able to learn the different concepts and skills and to succeed in mastering them. In addition, Enhancing the optimistic point of view makes them more able to develop the positive self - concept (Dreher, 1995). There are needs to consider psychological states of the children in 
order to know the ways of improving and enhancing their psychological health. The current study aimed to examine the effects of training sessions on children's levels of optimism and pessimism.

\section{The Study Problem}

Studying optimism and pessimism attitudes occupies great interest for the researchers because of the link of these aspects with the individual's psychological and physical health.

Most theories have confirmed the link of optimism with happiness, health accomplishment, hardworking and the positive view to the life. Optimism is a tendency to expect positive results rather than negative ones(Abu Al-Diyar, 2010).

(Marshall, et al. 1992) defined pessimism as readiness or embedded trait inside the individual leads to the negative expectation about the events, In addition, Carver \& Scherier, (2003) defined pessimism as the individuals' tendency towards the negative expectation about the future events. The pessimistic individual see the failure as catastrophe that it is impossible to get out of it, and generally unable to set the appropriate solutions to his daily problems which makes him continuously asking, and in a case of hesitation and doubt, and unable to depend on himself, often asks helps from others to perform the simplest works and functions (Seligman, 1995).

There are many studies that aimed to explain the differences between optimism and pessimism from the physiological point has looked at optimism as the general base for life and pessimism dies not fall in the individual's life unless formulated in him psychological problem (Abdurrahman, 1998). The individual can be consider optimistic if nothing happens in his/her life that creates a psychological problem to him/her, if the opposite occurs the person can be a pessimistic person (Al-Ansari, 2003).

While Al-saleem (2006) sees that optimism and pessimism as the individual's ability to acquire through imitating and simulating the others behavior when the motive is available. The social learning theory sees that the oral sensory stage formulated in the infant the sense of trust or un-trust that continue to be the self-source for hope, optimism, pessimism and despair during the rest of the life. (Abdurrahman, 1998).

The researchers see that there are many factors that have the impact on the child and make him either optimistic or pessimistic, these factors are:

1. The family: through the general climate that prevails in the family and the way of upbringing the children and implanting in them the values and the ideas, defusing security, care and assurance, all of this shape the child's personality and makes him either optimistic or pessimistic.

2. The school: including the teachers and principals who are optimistic, and extent of the reflection on the students' personalities.

3. The society: each society carry's its special feature. Either characterizes by optimism or pessimism, and of the emotions and social aspects specific to it and characterized by them through its exposure to economic and technological events and conditions.

4. The media: media have the great influence in the formation of the individuals emotions and casting them either by optimism or pessimism depending on their orientation to them.

5. Health: the person's optimism or pessimism affects his healthy life, the optimistic person is free form worry, anxiety \& depression, this helps him to acquire good health positive feature. (Hamdan, 1999).

From the previous illustration of the theories that explain optimism and pessimism, the researchers concluded that optimism and pessimism are the behaviors that the child might acquire through the environment, social upbringing, the school, the media, and the society surrounding the child.

\section{Literature Review}

Ibtisam (2011) conducted a study that aimed to examine the dimensions of optimism and pessimism among kindergarten children to discover their skills on crisis management and expanding the relation between training the children on optimism and developing their crisis's management in Alexandria City. The researcher used the children's intelligence test, optimism scale for the kindergarten children, crisis's management test for the kindergarten children. Note card for the children's behavior and the training program for teaching optimism . The result of the study showed that there wash statistically significance differences between the periods of the premeasuring and post- measuring on the dimensions of the optimistic behavior test due to of the training programIn 
addition, there was positive correlation with significance between optimistic behavior and the crisis's management skills.

Ruthing et al, (2009) conducted a study that aimed to know the effects of optimism and the social support on the psychological health of the first year new faculty students, also In addition the study aimed to know the extent of the academic control as mediator of the effects the social support and optimism on the psychological health of the new students. Study sample consisted of (288) students whom might suffering from depression and pressures. The results showed that optimism and social support predict less pressures and depression, In addition, the academic control mediates the precautionary effects of optimism and social support and increased by addition precaution to the students from the psychological health.

Coker, (2007) has studied the effect of the positive psychological on depression in terms optimism, psychological health, satisfaction, self-trust and personal happiness,. In addition, the researcher examined the effect of the negative emotions, the bad experiences on the childhood stage on depression, the results showed that the most influencing variable on the depression variable was optimism (in direct form)and the bad experiences at the childhood stage ( indirectly).

\section{Methodology}

There are many studies that were interested in studying optimism and pessimism, but the topic the optimism and pessimism among kindergarten children have not received that much of attentions among the researchers. children might join the kindergarten with little knowledge about the positive and negative behaviors that are associated with the optimism and pessimism. For instance, Al-hmairi, (2004), reported that level of optimism and pessimism are important factors that shape in the human behavior. The level of optimism and pessimism represent psychological state that would influence one's expectations regarding the present and the future.

Kindergarten children have pessimistic and optimistic attitudes and behaviors. Optimistic and pessimistic attitudes and behaviors are measurable. The current study aimed to measure Kindergarten children pessimistic and optimistic behaviors. In addition, the current study will investigate the effect of e effects of training sessions on children's levels of optimism and pessimism.

\subsection{The Study Questions}

\section{The study aimed to answer the following two questions}

1. What are the levels of Kindergarten children' pessimistic and optimistic attitudes?

2. What are the effects of the use of training session on the levels of Kindergarten children' pessimistic and optimistic attitudes?

\subsection{Study Population and Sample}

Study sample consisted of (21) e children, 8(38\%) females by and 13(62\%)males by their ages were between (5-6) years old, all the participants were from Sokayna Bent Al-Hussein school's kindergarten in Al-Shobak district, Jordan.

\subsection{Study Instrument}

The researcher used two instruments:

Training program to confirm the measurement of the children's optimism and pessimism level. This program consists of four aspects illustrated in the following table.

Table 1. Items of the Instruments Optimism and Pessimism

\begin{tabular}{llll}
\hline Motor aspect & Skill aspect & Cognitive aspect & Emotional aspect \\
\hline Running contests & Cutting and gluing & Stories hearing & $\begin{array}{l}\text { Learning the importance of } \\
\text { smiling }\end{array}$ \\
Rope pulling contests & $\begin{array}{l}\text { Drawing with colors and } \\
\text { clay }\end{array}$ & $\begin{array}{l}\text { Positively explaining the } \\
\text { events }\end{array}$ & $\begin{array}{l}\text { The importance of dealing } \\
\text { with all friends in } \\
\text { classroom }\end{array}$ \\
$\begin{array}{l}\text { Dancing and jumping in } \\
\text { front of all }\end{array}$ & $\begin{array}{l}\text { Disassembling and } \\
\text { assembling games }\end{array}$ & $\begin{array}{l}\text { Encouraging educational } \\
\text { situations of optimism }\end{array}$ & $\begin{array}{l}\text { Sympathy and helping } \\
\text { others }\end{array}$ \\
\hline
\end{tabular}


1- Note card to measure the kindergarten children's optimism and pessimism (prepared by the researchers), the note card consists of (12) items.

The children's responses were calculated by Likert three-point scale the high level (3) indicates that the child enjoys optimism, the middle (2), indicates that the child has percentage of optimism and percentage of pessimism, while the low level (1) which means the child is in a pessimism state

The validity of the instrument were checked by panel of experts of psychological, while the reliability was checked using Cronbach Alpha which was .89.

\section{Results}

\subsection{Study Hypothesis}

were there significant differences between the study sample individuals' mean before and after applying the program in favor of the post - measure in measuring the optimism and pessimism level of the kindergarten children?

Table (2), shows that there were significance differences between the means of the pre- observation and post-observation note cards for the kindergarten children's. Only cards number 8 and 11 showed that there were no significant differences between the pre- observation and post-observation.

Table 2. The Differences between the Means of the Children's Responses Before and After Applying the Program to the Optimism and Pessimism Concepts

\begin{tabular}{|c|c|c|c|c|c|c|c|}
\hline & Note card's & Note & Number & Mean & S.D & T-Value & $\begin{array}{l}\text { Significance } \\
\text { Level at } 0.05\end{array}$ \\
\hline \multirow[t]{2}{*}{1} & \multirow{2}{*}{$\begin{array}{l}\text { Continued the running contests till } \\
\text { the end }\end{array}$} & Pre & 21 & 25.42 & 3.753 & & \\
\hline & & Post & 21 & 31.00 & 2.335 & 7.41 & 0.00 \\
\hline \multirow[t]{2}{*}{2} & \multirow{2}{*}{$\begin{array}{l}\text { Participated in the rope pulling } \\
\text { contests }\end{array}$} & Pre & 21 & 1.58 & 0.668 & \multirow[t]{2}{*}{11.00} & \multirow[t]{2}{*}{0.00} \\
\hline & & Post & 21 & 2.50 & 0.522 & & \\
\hline \multirow[t]{2}{*}{3} & \multirow[t]{2}{*}{ Danced in front of the friends } & Pre & 21 & 1.91 & 0.792 & \multirow[t]{2}{*}{4.69} & \multirow[t]{2}{*}{0.01} \\
\hline & & Post & 21 & 2.58 & 0.514 & & \\
\hline \multirow[t]{2}{*}{4} & \multirow{2}{*}{$\begin{array}{l}\text { Completed the cutting and gluing } \\
\text { activities. }\end{array}$} & Pre & 21 & 2.16 & 0.717 & \multirow[t]{2}{*}{3.02} & \multirow{2}{*}{0.00} \\
\hline & & Post & 21 & 2.83 & 0.389 & & \\
\hline \multirow[t]{2}{*}{5} & \multirow[t]{2}{*}{ His drawings express optimism. } & Pre & 21 & 2.00 & 0.603 & \multirow[t]{2}{*}{4.690} & \multirow[t]{2}{*}{0.01} \\
\hline & & Post & 21 & 2.58 & 0.514 & & \\
\hline \multirow[t]{2}{*}{6} & \multirow{2}{*}{$\begin{array}{l}\text { Participation in the dissembling and } \\
\text { assembling games. }\end{array}$} & Pre & 21 & 2.00 & 0.603 & \multirow[t]{2}{*}{3.92} & \multirow[t]{2}{*}{0.02} \\
\hline & & Post & 21 & 2.66 & 0.492 & & \\
\hline \multirow[t]{2}{*}{7} & \multirow{2}{*}{$\begin{array}{l}\text { Explaining the stories events } \\
\text { optimistically. }\end{array}$} & Pre & 21 & 1.83 & 0.577 & \multirow[t]{2}{*}{-2.34} & \multirow[t]{2}{*}{0.03} \\
\hline & & Post & 21 & 2.41 & 0.541 & & \\
\hline \multirow[t]{2}{*}{8} & \multirow{2}{*}{$\begin{array}{l}\text { Deals with all of his friends in the } \\
\text { classroom with love. }\end{array}$} & Pre & 21 & 2.25 & 0.62 & \multirow{2}{*}{2.31} & \multirow{2}{*}{0.39} \\
\hline & & Post & 21 & 2.58 & 0.514 & & \\
\hline \multirow[t]{2}{*}{9} & \multirow[t]{2}{*}{ Empathetic. } & Pre & 21 & 2.16 & 0.777 & \multirow[t]{2}{*}{1.48} & 0.00 \\
\hline & & Post & 21 & 2.50 & 0.522 & & \\
\hline 10 & Asks about the stories heroes. & Pre & 21 & 2.33 & 0.51 & 1.48 & 0.00 \\
\hline & & Post & 21 & 2.50 & 0.522 & & \\
\hline 11 & Cares about hearing the story till the & Pre & 21 & 2.50 & 0.674 & -1.48 & 0.20 \\
\hline & end. & Post & 21 & 2.66 & 0.492 & & \\
\hline 12 & Smiling and cheerful. & Pre & 21 & 2.50 & 0.674 & 1.915 & 0.00 \\
\hline & & Post & 2.66 & 0.492 & & & \\
\hline
\end{tabular}




\section{Discussing}

The results of this study showed that there were significant differences between the study sample individuals' mean before and after applying the program in favor of the post - measure in measuring the optimism and pessimism level of the kindergarten children

The results showed that there were notable increases in the post - observation; this indicated the effects of applying the program to the study sample. It is possible to attribute the results to the characteristics of the training sessions to make the learner active and effective within educational positions far from the normal mode, full of excitement and enhancement elements.

The pessimistic students hold negative ideas that reduce their interest in the learning process and their push forth to participate in the different educational activities, and may be they hold low self - concept against their optimistic peers. The children's excellence in the post - observation in measuring the optimism and pessimism concepts might attribute to what the training program provides of skills and behaviors that enable the children to modify their behavior and attitudes towards the others and towards themselves. Since those items characterized by their coherence and integration, and their relevance to the targeted age category that make the program's items effective in achieving the goal they were designed for. The result of the current study aligned with the findings of Ahmad's,(2011) and Cooker's( 2007) studies.

\section{Suggestion and Recommendations}

In the light of the results of the study and the discussion, the researchers recommend the following:

1. Conducting more studies about measuring the positive and negative behaviors of the kindergarten children in order to enhance the positive behaviors such as optimism and attempting to modify the negative behaviors like pessimism.

2. The researchers recommend the kindergarten female teachers to care about the different aspects of the kindergarten child's personality, and not only focusing on the cognitive aspect, also explaining the life's situations in a positive and national way far from the superstitious.

3. The researchers recommend the fathers and the mothers to know the different traits and features of the children's personalities that will help them in understanding and explaining the life's situations in a realistic and optimistic way.

4. Also, the researchers recommend the teachers and the parents to enhance the optimistic point of view of the kindergarten children and the students because of its effect on developing their personality.

\section{References}

Abdurrahman, M. (1998). Personality Theories, Dar Qiba for Press and Publication (1st Edition). Cairo, Egypt.

Abu aldiyar, M. (2010). Effectiveness of Programs for the Rational Emotional Counseling in Developing the Optimism to Reduce the Severity of the Psychological Pressures of a Sample of Families with Hearing Impairment Children. Journal of Social Sciences, Kuwait University, 38(3).

Ahmad, I. (2011). Effectiveness of a Training Program for the Learned Optimism in Developing Some Skills of Crises Management of the Kindergarten Children. (Unpublished Doctorate Dissertation).

Al- Shal, R. (2008). Effectiveness of a Program to Kindergarten Children.(Unpublished Master Thesis), Ain Shams University, Egypt.

Al-Ansari, B. (2003). Optimism and Pessimism: Measuring them and their Relation With some of the Personality Variables of the University of Kuwait Students. Journal of Annual Literatures and social sciences, Al-Resalah 192, twenty-three Annual, Council of the Scientific Publication University of Kuwait - Kuwait.

Al-Hameeri, A. (2004). Measuring Optimism and Pessimism in the University Students in Yaman. Journal of faculty of Education, Ain Shams University.

Al-Saleem, H. (2006). Optimism, Pessimism, and their Relation to the Personality's Five Grate Factors in a Sample of Female Students in King of Saud University, (Unpublished Master Thesis). University of King Saud.

Bdair, K. (2011). Kindergarten Child's Problem and their Treatment Methods, (2nd edition). Dar Al Messerah for Publication and Distribution, Amman - Jordan. 
Carver, C. S., \& Scheier, M. F. (2003). Optimism. In S. J. Lopez and C. R. Snyder (Eds.), Handbook of Positive Psychology Assessment: a Handbook of Models and Measures. Washington, DC: American Psychological Association. p. 75-89. http://dx.doi.org/10.1037/10612-005

Coker, S. (2007). A Positive Psychological Perspective of the Direct and Indirect Influences of Gender Role Schema and the Experience of Childhood Trauma on Psychological, Physical and Social Well-Being in Adulthood. (Unpublished Doctoral Dissertation). the Central Queensland University.

Dreher, H (1995). The Immune Power Personality. Adutton Book. USA.

Hamdan, F. (1999). Psychology of Optimism and Pessimism of the General Secondary Students in the Public Schools in Jineen District, (Unpublished Master Thesis). Al-Najah National University, Nablus - Palestine.

Marshall, G. N., Wortman, C. B., \& Kusulas, J. et al. (1992). Distinguishing Optimism from Pessimism: Relations to Fundamental Dimensions of Mood and Personality. Journal of Personality and Social Psychology, 62(6), 1067-1074. http://dx.doi.org/10.1037/0022-3514.62.6.1067

Mkhaimar, H., \& Abdallmoti, M., A. (2000). Optimism and Pessimism and Variables in a Sample of a University Male and Female Students. Journal of Social and Education, Helwan University, 6(3).

Ruthing, C. (2009). Perceived Academic Control: Mediating the Effects of Optimism and Social Support on College Student Psychological Health. Social Psychology of Education, 12(2), $233-249$. http://dx.doi.org/10.1007/s11218-008-9079-6

Seligman, M. E. (1995). The Optimistic Child. New York: Houghton Mifflin.

Vaughan, S., C. (2000). Half Empty, Half Full: Understanding the Psychological Roots of Optimism. New York: Courtyard. 